P-ISSN: 1979-052X e-ISSN: 2614-6215 November 2017
Ijtimaiyya: Jurnal Pengembangan Masyarakat Islam 10 (2) (2017) 241-272

https://ejournal.radenintan.ac.id/index.php/ijtimaiyya/index

\title{
PELAKSANAAN TUGAS PEMBANTU PEGAWAI PENCATAT NIKAH PASCA INSTRUKSI DIRJEN BIMAS ISLAM NOMOR DJ.II/1 TAHUN 2015
}

(Studi di KUA Berbagai Tipe di Provinsi Lampung)

\author{
Ali Firdaus \\ Pegawai KUA Kota Metro Provinsi Lampung \\ email: alifirdaus@yahoo.com \\ Diterima: 15 Juni 2017. Disetujui: 07 Oktober 2017 \\ Dipublikasikan: November 2017
}

\begin{abstract}
The Ministry of Religious Affairs decided not to extend the term of Assistant Employee of Marriage Registerer (PPPN). Then the Directorate General of Islamic Guidance issued the Instruction Letter No. DJ.II / 1 Year 2015 on the Appointment of the Marriage Officer. The PPPN appointment recommendation that KUA is included in typology D1 and D2, ie: the subdistrict area is not reachable by the marriage officer and the limited of human resources. This problems arise in a number of regions in Indonesia, and also in Lampung Province. This research finds that after the instruction of the Director General of Islamic Guidance, PPPN in KUA Natar, Padang Cermin, Tanjung Karang Pusat and Marga Punduh can be concluded as follows: Since that enactment, PPPN at KUA Tanjung Karang Bandar Lampung is no longer perform the duties. While in KUA District Natar, KUA District Padang Cermin and KUA District Marga Punduh partially PPPN still carry out the task of recording marriage.
\end{abstract}

Keywords: Pembantu PPN, Pencatatan Perkawinan

\section{A. Pendahuluan}

Pencatatan perkawinan pada prinsipnya merupakan hak dasar dalam keluarga. Selain itu merupakan upaya perlindungan terhadap isteri maupun anak dalam 
memperoleh hak-hak keluarga seperti hak waris dan lain-lain. Pencatatan perkawinan juga penting bagi pihak laki-laki jika suatu saat terjadi permasalahan dalam perkawinannya. Dalam hal nikah siri atau perkawinan yang tidak dicatatkan dalam administrasi negara, perkawinan tersebut tidak memiliki kekuatan hukum karena tidak mendapat legalitas negara.

Dalam hukum di Indonesia, persoalan perkawinan telah diatur dalam Undang-Undang Nomor 1 Tahun 1974 tentang Perkawinan. Pengaturan pencatatan perkawinan bagi pasangan pengantin menjadi bagian yang penting di dalamnya. Pasal 2 Undang-undang Nomor 1 Tahun 1974:

(1) Perkawinan adalah sah, apabila dilakukan menurut hukum masing-masing agamanya dan kepercayaannya itu.

(2) Tiap-tiap perkawinan dicatat menurut peraturan perundang-undangan yang berlaku. ${ }^{1}$

Dalam Peraturan Pemerintah Nomor 9 Tahun 1975 tentang Pelaksanaan Undang-undang Nomor 1 Tahun 1974 tentang Perkawinan dinyatakan bahwa pasangan yang melakukan perkawinan secara Islam, harus diawasi oleh Pegawai Pencatat Nikah (PPN). Bagi Warga Negara Indonesia yang beragama Islam, pencatatan nikahnya dilaksanakan pada Kantor Urusan Agama (KUA) Kecamatan.

Pada tahun 1983 Kementerian Agama mengeluarkan Peraturan Menteri Agama Nomor 6 Tahun 1983 tentang Penunjukan dan Pemberhentian Serta Kewajiban dan Hak Pembantu Pegawai Pencatat Nikah. Salah satu pertimbangannya adalah karena luas dan sulitnya akses transportasi di wilayah luar Jawa dan Madura sehingga menyulitkan masyarakat mengurus pencatatan nikah. Oleh karena itu untuk mempermudah masyarakat maka di setiap desa perlu diadakan Pembantu Pegawai Pencatat Nikah yang

${ }^{1}$ Direktorat Jenderal Bimbingan Masyarakat Islam Kementerian Agama RI, Himpunan Peraturan Perundang-undangan Perkawinan, (Jakarta : 2015), h. 22. 
disingkat Pembantu PPN. ${ }^{2}$

Meskipun banyak sisi manfaat dalam pengangkatan Pembantu PPN, namun keberadaan mereka juga tidak terlepas dari masalah. Pembantu PPN diangkat dan diperbantukan pada Kementerian Agama namun tidak diiringi dengan kejelasan penghasilan dari profesi yang dijalaninya. Dalam surat keputusan Kepala Kantor Kementerian Agama Kabupaten/Kota, pengangkatan Pembantu PPN tidak menyebutkan honorarium atau penghasilan dari tugas yang dilaksanakan. Oleh karena itu banyak ditemukan Pembantu PPN memungut biaya pencatatan nikah melebihi ketentuan, dimana sebagian dari biaya tersebut masuk ke kantong pribadi. Penghasilan Pembantu PPN diperoleh dari uang jasa yang diberikan masyarakat yang memperloleh pelayanan nikah atau rujuk. Hal tersebut yang membuat terjadinya pembengkakan biaya pencatatan nikah atau rujuk.

Masalah lainnya yang sering ditemukan adalah sebagian masyarakat tidak tahu tentang tugas-tugas pokok Pembantu PPN, sehingga menganggap Pembantu PPN itu sama saja dengan PPN dan Penghulu. Masih banyak masyarakat yang hendak menikah tidak mendatangi KUA kecamatan, namun datang ke Pembantu PPN.

Untuk menertibkan pelayanan pencatatan nikah dan rujuk pada KUA Kecamatan dan menata keberadaan Pembantu PPN, Direktorat Jenderal Bimbingan Masyarakat Islam Kementerian Agama mengeluarkan Surat Instruksi Nomor DJ.II/113/2009 tentang Penggunaan Dana PNPB Nikah/Rujuk dan Penataan Pembantu Pegawai Pencatat Nikah. Pada poin kedua diinstruksikan kepada Kantor Wilayah Departemen Agama Provinsi seluruh Indonesia untuk melakukan penghentian pengangkatan Pembantu PPN yang telah habis masa waktunya dan tidak mengangkat Pembantu PPN baru, kecuali bagi daerah-daerah yang sangat

${ }^{2}$ Pembantu Pegawai Pencatat Nikah ini banyak singkatannya di masyarakat. Ada yang menyebut Pembantu PPN, P3N dan Pembantu Penghulu. Penulis menggunakan singkatan Pembantu PPN sebagaimana disebutkan dalam PMA Nomor 11 Tahun 2007 tentang Pencatatan Nikah. 


\section{Ijtimaiyya: Jurnal Pengembangan Masyarakat Islam 10 (2) (2017)}

memerlukan dengan persetujuan tertulis dari Dirjen Bimas Islam Kementerian Agama. ${ }^{3}$

Instruksi ini belum efektif menata keberadaan Pembantu PPN. Kemudian pada tanggal 26 Januari 2015 Ditjen Bimbingan Masyarakat Islam kembali mengeluarkan Surat Instruksi Nomor DJ.II/1 Tahun 2015 tentang Pengangkatan Pegawai Pencatat Nikah. ${ }^{4}$ Rekomendasi pengangkatan Pembantu PPN harus memperhatikan bahwa KUA tersebut masuk dalam tipologi D1 dan D2. Pengangkatan Pembantu PPN juga harus dilakukan dengan didasarkan pada kebutuhan. Yaitu wilayah kecamatan memang tidak bisa dijangkau oleh Petugas Pencatat Nikah dan terbatasnya SDM dibanding luas wilayah.

Tipologi KUA Kecamatan adalah klasifikasi KUA kecamatan yang ditentukan berdasarkan jumlah peristiwa nikah dan rujuk per bulan, dan kondisi geografis. Tipologi A adalah KUA yang jumlah nikah dan rujuknya di atas 100 peristiwa per bulan. Tipologi B yaitu jumlah nikah dan rujuk antara 51 sampai dengan 100 peristiwa per bulan. Sedangkan tipologi $\mathrm{C}$ adalah KUA dengan jumlah nikah dan rujuk di bawah 50 peristiwa per bulan.

Selain itu, ada juga KUA tipologi D1, yaitu KUA Kecamatan yang secara geografis berada di daerah terluar, terdalam, dan di daerah perbatasan daratan. Terakhir tipologi D2, yaitu KUA Kecamatan yang secara geografis berada di daerah terluar, terdalam, dan daerah perbatasan kepulauan. ${ }^{5}$ Masalah muncul di sejumlah daerah di Indonesia, salah

${ }^{3}$ Instruksi ini terbit pada tanggal 10 Februari 2009. Dalam Instruksi ini Kementerian Agama Kabupaten/Kota diinstruksikan melakukan konsolidasi dan koordinasi dengan masing-masing Pemerintah Daerah untuk menempatkan Pembantu PegawaiPencatat Nikah sebagai bagian dari aparat Pemerintah Desa/Kelurahan.

${ }^{4}$ Mukharam Ibrahim, Kepala Bidang Urusan Agama Islam dan Pembinaan Syari'ah Kantor Wilayah Kementerian Agama Provinsi Lampung, wawancara tanggal 6 September 2016).

5Peraturan Menteri Agama Nomor 12 Tahun 2016 tentang Pengelolaan PNBP Atas Biaya Nikah atau Rujuk di Luar KUA Kecamatan. 
satunya di Provinsi Lampung. Berdasarkan data dari Kantor Wilayah Kementerian Agama Provinsi Lampung, dari 203 KUA kecamatan hanya 17 KUA yang termasuk dalam tipologi D1 dan tidak ada KUA tipologi D2. ${ }^{6}$ Padahal banyak KUA kecamatan di Provinsi Lampung yang kekurangan jumlah Penghulu bahkan tidak ada sama sekali serta mempunyai wilayah yang luas dan sulit dijangkau. Makalah ini hendak memotret keberadaan Pembantu PPN di setiap tipologi KUA yang ada di Provinsi Lampung. KUA Kecamatan yang menjadi lokasi penelitian adalah KUA Kecamatan Natar (Tipologi A), KUA Kecamatan Padang Cermin (Tipogi B), KUA Kecamatan Tanjung Karang Pusat (Tipologi C), dan KUA Kecamatan Marga Punduh (Tipologi D1).

\section{B. Pembahasan}

\section{Pengertian Pencatatan Nikah}

Secara bahasa pencatatan adalah proses, cara, atau perbuatan mencatat. ${ }^{7}$ Pencatatan nikah adalah kegiatan menulis yang dilakukan oleh seseorang mengenai suatu peristiwa pernikahan yang terjadi. Dalam UU Perkawinan tidak disebutkan secara tegas pengertian pencatatan perkawinan. Namun demikian dilihat dari konteks kalimat yang digunakan dihubungkan dengan kegiatan pencatatan perkawinan yang diatur dalam Peraturan Pemerintah Nomor 9 Tahun 1975, maka dapat diketahui bahwa pencatatan perkawinan adalah suatu tindakan hukum mencatat pernikahan oleh Pegawai Pencatat Nikah untuk selanjutnya diwujudkan dalam bentuk akta dijadikan sebagai bukti sah terjadinya peristiwa pernikahan.

${ }^{6}$ Surat Keputusan Kepala Kantor Wilayah Kementerian Agama Provinsi Lampung Nomor Kw.08.5/HK.00.8/097/2015 tentang Penetapan Tipologi Kantor Urusan Agama Kecamatan Di Lingkungan Kanwil Kementerian Agama Provinsi Lampung.

${ }^{7}$ Kamus Besar Bahasa Indonesia Online, http://kbbi.web.id/catat diakses tanggal 14 September 2016. 
Perbuatan pencatatan nikah tersebut menurut $K$. Wantjik Saleh, tidak menentukan sahnya suatu perkawinan, tapi menyatakan bahwa peristiwa perkawinan itu memang ada dan terjadi, jadi semata-mata bersifat administratif. Sedangkan soal sahnya perkawinan, UU Perkawinan dengan tegas menyatakan pada Pasal 2 ayat (1) bahwa perkawinan adalah sah apabila dilakukan menurut hukum masing-masing agama dan kepercayaannya. ${ }^{8}$

Pernikahan merupakan suatu ikatan/akad/transaksi, yang di dalamnya sarat dengan kewajiban-kewajiban dan hak, bahkan terdapat pula beberapa perjanjian pernikahan. ${ }^{9}$ Selain itu dapat diketahui dari Undang-Undang Nomor 23 Tahun 2006 tentang Administrasi Kependudukan menjelaskan mengenai pencatatan sipil yang mana dalam Pasal 1 angka (15) menjelaskan bahwa pencatatan sipil adalah pencatatan peristiwa penting yang dialami oleh seseorang dalam register Pencatatan Sipil pada instansi.

\section{Tujuan Pencatatan Nikah}

Pada dasarnya, fungsi pencatatan pernikahan pada KUA atau kantor catatan sipil adalah agar seseorang memiliki alat bukti (bayyinah) untuk membuktikan bahwa dirinya benarbenar telah melakukan pernikahan dengan orang lain. Sebab, salah bukti yang dianggap sah sebagai bukti Syar'i (bayyinah syar'iyyah) adalah dokumen resmi yang dikeluarkan oleh negara. Ketika pernikahan dicatatkan pada lembaga negara, tentunya seseorang telah memiliki sebuah dokumen resmi yang bisa ia dijadikan sebagai alat bukti di hadapan lembaga peradilan. Ketika ada sengketa yang berkaitan dengan pernikahan, maupun sengketa yang lahir akibat pernikahan, seperti waris, hak asuh anak, perceraian, nafkah, dan lain

${ }^{8}$ O.S. Eoh, Perkawinan Antar Agama Dalam Teori dan Praktek, (Jakarta: PT Raja Grafindo Persada, 1996), h. 98-99.

${ }^{9} \mathrm{M}$. Anshary MK, Hukum Perkawinan di Indonesia, (Yogyakarta: Pustaka Pelajar, 2010), h. 21. 
sebagainya. ${ }^{10}$

Selain itu disebutkan dalam UU No. 22 tahun 1946 bahwa tujuan dicatatkannya perkawinan adalah agar mendapat kepastian hukum dan ketertiban. Dalam penjelasan pasal 1 ayat (1) UU tersebut dijelaskan bahwa:

Maksud pasal ini ialah agar nikah. talak dan rujuk menurut agama Islam dicatat agar mendapat kepastian hukum. Dalam Negara yang teratur segala hal-hal yang bersangkut paut dengan penduduk harus dicatat, sebagai kelahiran, pernikahan, kematian dan sebagainya. Lagi pula perkawinan bergandengan rapat dengan waris-mal-waris sehingga perkawinan perlu dicatat menjaga jangan sampai ada kekacauan.Kompilasi Hukum Islam menjelaskan tentang tujuan pencatatan nikah, dalam pasal 5 yakni :

1. Agar terjamin ketertiban perkawinan bagi masyarakat Islam, setiap pernikahan harus dicatat.

2. Pencatatan pernikahan tersebut pada ayat (1) dilakukan oleh Pegawai Pencatat Nikah sebagaimana diatur dalam Undang-Undang Nomor 22 Tahun 1974 jo. UndangUndang Nomor 32 Tahun 1945.

Melalui pencatatan nikah yang dibuktikan dengan akta nikah, yang masing-masing suami isteri mendapat salinannya, apabila terjadi perselisihan atau percekcokan di antara mereka atau salah satu tidak bertanggung jawab, maka yang lain dapat melakukan upaya hukum guna mempertahankan atau mendapatkan haknya masing-masing. Karena dengan akta tersebut, suami isteri memiliki bukti otentik atas pernikahan yang telah mereka lakukan. ${ }^{11}$

Banyak kerugian hukum jika suatu perkawinan tidak dicatatkan oleh negara. Apabila tidak dilakukan pencatatan nikah, maka akibat hukumnya antara lain:

\footnotetext{
${ }^{10}$ Pencatatan Perkawinan Dalam Hukum Islam, https://aljurem.wordpress.com/ diakses tanggal 23 Februari 2017.

${ }^{11}$ Ahmad Rofiq, Hukum Perdata Islam di Indonesia (Jakarta: PT Raja Grafindo Persada, 2013), h. 91.
} 
1. Dipandang oleh sebagian masyarakat sekitarnya sebagai kumpul kebo atau istri simpanan;

2. Tidak ada perlindungan hukum terhadap perkawinan karena bagi negara dipandang tidak terjadi perkawinan (ada namun dipandang secara juridis tidak ada/tidak terjadi, sesuai Jurisprudensi Mahkamah Agung Putusan Nomor 1948/K/Pid/1991 tanggal 18 Desember 1991);

3. Ditolak berperkara tentang masalah hukum keluarga di (nikah, talak, rujuk, hadhanah, iddah, harta gono-gini dan waris) di Pengadilan Agama karena perkawinan tidak dapat dibuktikan, kecuali dilakukan itsbat nikah;

4. Pihak istri sewaktu-waktu dapat diceraikan suaminya atau suami sewaktu-waktu dapat berpoligami tanpa, bahkan dapat mengingkari perkawinan dan anak-anak hasil perkawinan tersebut, sedangkan istri tidak memiliki kekuatan hukum untuk melakukan perlawanan hukum di Pengadilan Agama.

5. Tidak ada alat bukti sah untuk menegaskan asal-usul anak dan keturunan.

6. Sulit melakukan pengurusan administrasi kependudukan.

7. Ditolak berperkara di Pengadilan dalam Perkara Pidana Perkawinan (misalnya zina), sesuai Yurisprudensi Mahkamah Agung RI Putusan Nomor 1948/K/Pid/1991 tanggal 18 Desember 1991, dalam pertimbangan hukumnya menyatakan bahwa yang dimaksud dengan "Perkawinan" menurut Undangundang No. 1/1974, PP No. 9/1975, adalah perkawinan yang dilangsungkan di hadapan KUA oleh petugas KUA yang berwenang serta perkawinan tersebut didaftarkan menurut tatacara perundangundangan yang berlaku; karena itu perkawinan yang tidak memenuhi persyaratan tersebut dianggap tidak ada perkawinan, sehingga tidak dapat dipidanakan sebagaimana dimaksud Pasal 279 KUHPidana (kurungan penjara 5 tahun). 


\section{Dasar Hukum Pencatatan Nikah}

Pada dasarnya, konsep pencatatan nikah merupakan suatu bentuk pembaruan yang dilakukan dalam bidang hukum keluarga Islam. Hal ini disebabkan oleh tidak diungkapnya keharusan pencatatan nikah di dalam al-Qur'an dan Hadits Nabi. Atas dasar inilah, para ulama fikih juga tidak memberikan perhatian serius terhadap pencatatan nikah.

Ada beberapa hal yang dianggap sebagai faktor penyebab pencatatan nikah luput dari perhatian para ulama pada masa awal Islam:

1. Adanya larangan dari Rasulullah untuk menulis sesuatu selain al-Qur'an. Tujuannya untuk mencegah tercampurnya al-Qur'an dari yang lain. Akibatnya, kultur tulis menulis tidak begitu berkembang dibandingkan dengan kultur hafalan.

2. Kelanjutan dari yang pertama, mereka sangat mengandalkan ingatan (hafalan). Agaknya mengingat suatu peristiwa nikah bukanlah hal yang sulit untuk dilakukan.

3. Tradisi walimah al urusy yang dilakukan dianggap telah menjadi saksi, di samping saksi syar'i tentang suatu pernikahan. ${ }^{12}$

4. Perkawinan yang berlangsung pada masa-masa awal Islam belum terjadi antar wilayah negara yang berbeda. Biasanya perkawinan pada masa itu berlangsung dimana calon suami dan calon istri berada dalam suatu wilayah yang sama. Sehingga alat bukti kawin selain saksi belum dibutuhkan. ${ }^{13}$

Dengan demikian, terlihat bahwa pada masa awal Islam, pencatatan nikah sebagai alat bukti yang otentik belum lagi dibutuhkan. walaupun pencatatan nikah belum dilakukan

${ }^{12}$ Amir Nuruddin dan Azhari Akmal Tarigan, Op Cit, h. 121.

${ }^{13}$ Amir Syarifuddin. Hukum Perkawinan Islam di Indonesia. (Jakarta: Prenada Media, 2006), h. 11. 
pada masa itu, namun, spirit dan substansi yang ingin dicapai dari pencatatan nikah telah dimanifestasikan, meskipun dalam bentuk yang lebih sederhana. Terkait dengan hal ini, menurut Atho' Mudzhar dalam bukunya "Membaca Gelombang Ijtihad, Antara Tradisi dan Liberasi", pencatatan nikah yang dilakukan saat ini harus dilihat sebagai bentuk baru cara mengumumkan pernikahan (i'lan al nikah). ${ }^{14}$

Lebih jauh lagi, pencatatan nikah ini dianggap lebih maslahat terutama bagi perempuan dan anak-anak. Namun sesungguhnya pencatatan nikah itu banyak kegunaannya bagi kedua belah pihak yang melaksanakan pernikahan baik dalam kehidupan pribadi maupun dalam hidup bermasyarakat. ${ }^{15}$

Sebagian besar ulama Indonesia dalam lokakarya alim ulama Indonesia pada tanggal 2 s.d. 5 Februari 1991 telah menerima dengan baik dan menyepakati isi KHI (Kompilasi Hukum Islam). Salah satu isi KHI, khususnya pasal 5 menegaskan:

(1)Agar terjamin ketertiban perkawinan bagi masyarakat Islam setiap perkawinan harus dicatat.

(2) Pencatatan perkawinan tersebut pada ayat (1), dilakukan oleh Pegawai Pencatat Nikah sebagaimana yang diatur dalam Undang-undang Nomor 22 Tahun 1946 jo Undang-undang No. 32 Tahun 1954.

Dengan kata lain, sebagian besar ulama Indonesia sepakat bahwa pencatatan nikah merupakan bagian dari hukum yang wajib ditaati oleh umat Islam. Dari uraian ini maka dapat ditegaskan bahwa pencatatan nikah mempunyai dalil syar'i dalam hukum Islam. Pandangan yang mengatakan bahwa pencatatan nikah hanyalah peraturan negara atau hukum positif saja harus dikritisi karena telah menyempitkan landasan hukum pencatatan nikah.

${ }^{14} \mathrm{M}$. Atho' Mudzhar, Membaca Gelombang Ijtihad, Antara Tradisi dan Liberasi, (Yogyakarta: Titian Ilahi Press, 1998), h. 105.

${ }^{15}$ Soemiyati, Hukum Perkawinan Islam dan Undang-Undang Perkawinan, (Yogyakarta: Liberty, 1999), h. 66. 
Berdasarkan hal-hal tersebut maka berdasarkan pertimbangan Maslahah Mursalab dalam hukum Islam, pencatatan nikah adalah suatu perbuatan yang harus dilaksanakan. Maslahah Mursalab sendiri ialah menetapkan ketentuan-ketentuan hukum yang tidak disebutkan sama sekali di dalam al-Qur'an atau Sunnah Rasul atas pertimbangan menarik kebaikan dan menolak kerusakan dalam hidup bermasyarakat. Dengan demikian dapat ditegaskan bahwa pencatatan perkawinan merupakan ketentuan yang perlu diterima dan dilaksanakan oleh semua pihak karena memiliki landasan yang kokoh yaitu Maslahah Mursalah (suatu metode berpikir yang dibangun atas dasar kejadian induktif). ${ }^{16}$

\section{Pencatatan Nikah Menurut Hukum Positif di Indonesia}

Tata cara perkawinan di Indonesia tergolong beraneka ragam antara satu dengan yang lainnya oleh karena di Indonesia mengakui adanya bermacam-macam agama dan kepercayaan, yang tata caranya berbeda. Hal yang demikian dimungkinkan dalam Negara Republik Indonesia yang berdasarkan Pancasila yang dengan tegas mengakui adanyaprinsip kebebasan beragama. ${ }^{17}$

Sebelum lahirnya UU Perkawinan yang merupakan peraturan perundang-undangan yang bersifat Nasional, Pemerintah mengadopsi peraturan dari Zaman Pemerintah Hindia Belanda yang membagi masyarakat kedalam beberapa golongan penduduk, dengan adanya golongan penduduk ini, maka perkawinan di Indonesia diatur dalam:

1. Bagi orang Indonesia asli yang beragama Islam berlaku Hukum Agama Islam.

16 Abd. Rasyid As'ad, Urgensi Pencatatan Perkawinan Dalam Perspektif Filsafat Hukum, http://www.arsip.badilag.net/ diakses tanggal 24 Juni 2016. 2002), h. 1.

${ }^{17}$ Subekti, HukumKeluargadanHukumWaris,(Jakarta: PT.Intermasa, 
2. Bagi orang Indonesia asli lainnya, berlaku hukum adat daerah masing-masing.

3. Bagi orang Indonesia asli yang beragama Kristen berlaku Huwelijks Ordonantie Christien Indonesier (S. 1993 No.74) selanjutnya disebut HOCI.

4. Bagi orang Timur Asing Cina dan Warga Negara Indonesia keturunan cina berlaku ketentuan Kitab Undang-undang Hukum Perdata dengan sedikit perubahan.

5. Bagi orang Timur Asing lain-lainnya dan Warga Negara Indonesia keturunan Timur Asing lainnya, berlaku hukum adat mereka. ${ }^{18}$

Setelah berlakunya UU Perkawinan, maka terjadi unifikasi hukum dalam perkawinan di Indonesia, dimana perkawinan mempunyai hubungan yang sangat erat dengan agama/kerohanian. Pengaturan hukum tentang perkawinan telah berlaku sama terhadap semua warga Negara, oleh karena itu setiap warga negara harus patuh terhadap hukum yang berlaku, termasuk terhadap UU Perkawinan yang menjadi landasan untuk menciptakan kepastian hukum, baik dari sudut hukum keluarga, harta benda, dan akibat hukum dari suatu perkawinan. ${ }^{19}$

Hal yang penting ketika membahas perkawinan adalah keabsahan/validitas perkawinan. UU Perkawinan Pasal 2 menyatakan bahwa:

1. Perkawinan adalah sah, apabila dilakukan menurut hukum masing-masing agamanya dan kepercayaannya itu

2. Tiap-tiap perkawinan dicatat menurut peraturan perundang-undangan yang berlaku.

${ }^{18}$ Hilman Hadikusuma, Hukum Perkawinan Indonesia Menurut Perundangan, Hukum Adat, Hukum Agama, (Bandung: CV. Mandur Maju, 2007), h. 5.

${ }^{19} \mathrm{~K}$. Wantjik Saleh, Hukum Perkawinan Indonesia, Jakarta: Ghalia Indonesia, 1982), h. 3. 
Secara sepintas dua ayat tersebut tidak bermasalah karena mengatur dua hal yang berbeda, pertama mengatur tentang keabsahan perkawinan, kedua mengatur tentang pencatatan perkawinan. Namun kemudian muncul ketentuanketentuan tentang pencatatan perkawinan yang lebih tegas yang prinsipnya menyatakan keharusan melakukan pencatatan perkawinan, perkawinan harus dilangsungkan di hadapan dan di bawah pengawasan Pegawai Pencatat Nikah dan jika melanggarnya dipidana serta perkawinan yang tidak dicatatkan tidak mempunyai kekuatan hukum tetap. ${ }^{20}$

Terhadap pencatatan nikah pemerintah RI telah mengaturnya dalam Undang-Undang Nomor 22 Tahun 1946 Tentang pencatatan Nikah, Talak dan Rujuk. UndangUndang ini pertama-tama hanya berlaku untuk Jawa dan Madura, yaitu mulai 1 Februari 1947. Baru sesudah tahun 1954 undang-undang ini diberlakukan secara menyeluruh di Indonesia, yaitu dengan terbitnya Undang-Undang No. 32 Tahun 1954 tentang tentang pencatatan nikah, talak dan rujuk berlaku untuk seluruh daerah luar Jawa dan Madura. Undangundang ini disahkan pada tanggal 26 Oktober 1954 oleh Presiden Soekarno.

Tata cara pencatatan nikah berpedoman kepada Peraturan Pemerintah Nomor 9 Tahun 1975 tentang Pelaksanaan Undang-undang Nomor 1 Tahun 1974 tentang Perkawinan. Pencatatan perkawinan dijelaskan dalam Bab II PP Nomor 9 Tahun 1975. Mengenai kewenangan lembaga yang melaksanakan pencatatan perkawinan diatur dalam Pasal 2:

1) Pencatatan perkawinan dari mereka yang melangsungkan perkawinannya menurut agama Islam, dilakukan oleh Pegawai Pencatat sebagaimana dimaksud dalam Undang-undang Nomor 32 Tahun

${ }^{20}$ Lihat Peraturan Pemerintah Republik Indonesia Nomor 9 Tahun 1975 Tentang Pelaksanaan Undang-Undang Nomor 1 Tahun 1974 Tentang Perkawinan, pada Pasal 3 ayat (1), Pasal 10 ayat (3) danPasal 45 ayat (1) huruf (a) dan Kompilasi Hukum Islam, pada Pasal 5 dan 6. 
1954 tentang Pencatatan Nikah, Talak dan Rujuk.

2) Pencatatan perkawinan dari mereka yang melangsungkan perkawinannya menurut agamanya dan kepercayaannya itu selain agama Islam, dilakukan oleh Pegawai Pencatat perkawinan pada kantor catatan sipil sebagaimana dimaksud dalam berbagai perundang-undangan mengenai pencatatan perkawinan.

Kemudian di dalam pasal 10 ayat (3) Peraturan Pemerintah Nomor 9 Tahun 1975 menentukan bahwa pernikahan dilaksanakan dihadapan pegawai pencatat yang dihadiri oleh dua orang saksi. Fungsi pencatat disebutkan pada angka 4.b. Penjelasan Umum Undang-undang Nomor 1 Tahun 1974: Pencatatan tiap-tiap pernikahan adalah sama halnya dengan pencatatan peristiwa-peristiwa penting dalam kehidupan seseorang, misalnya kelahiran, kematian yang dinyatakan dalam surat-surat keterangan, suatu akta juga dimuat dalam daftar pencatatan.

Perintah pasal 2 ayat (2) Undang-Undang Nomor 1 Tahun 1974 untuk melakukan pencatatan terhadap suatu pernikahan tersebut ditujukan kepada segenap warga negara Indonesia apakah ia berada di Indonesia atau di luar Indonesia.

Pasal 10 ayat (3) Peraturan Pemerintah Nomor 9 Tahun 1975 mengatur bahwa pernikahan harus dilaksanakan dihadapan pegawai pencatat yang dihadiri oleh dua orang saksi. Pasal 11 ayat (1) dan ayat (3) menyatakan bahwa sesaat sesudah pernikahan dilangsungkan, kedua mempelai menandatangani akta pernikahan tersebut, pernikahan tersebut telah tercatat secara resmi. Selanjutnya menurut pasal 13 ayat (2), kepada masing-masing suami isteri diberikan kutipan akta pernikahan tersebut. Dengan diperolehnya kutipan akta pernikahan itu pernikahan mereka telah dinyatakan sebagai pernikahan yang mempunyai hak 
mendapat pengakuan dan perlindungan hukum. ${ }^{21}$ Di Indonesia pencatatan nikah bagi warga Negara yang beragama Islam dilaksanakan pada Kantor Urusan Agama (KUA) kecamatan. KUA memiliki tata cara dan prosedur pencatatan nikah sebagaimana diatur dalam KMA 298 Tahun 2003 yang disesuaikan dengan PMA 477 Tahun 2004 dan disempurnakan dengan PMA Nomor 11 Tahun 2007 tentang Pencatatan Nikah.

\section{Pembantu PPN}

Keberadaan Pembantu Pegawai Pencatat Nikah tidak terlepas dari keberadaan Pegawai Pencatat Nikah (PPN). Berdasarkan Pasal 1 ayat (1) dan (2) Undang-undang Nomor 22 Tahun 1946 jo. Undang-undang Nomor 32 Tahun 1954 menegaskan bahwa PPN bagi umat Islam diangkat oleh Menteri Agama atau diangkat oleh pegawai yang ditunjuk oleh Menteri Agama.

Terbitnya UU Nomor 22 Tahun 1946 yang mengatur tentang pencatatan peristiwa perkawinan menjadikan munculnya Pegawai Pencatat Nikah. Pada tahun 1950-an muncul istilah pencatatan Nikah, Talak, Cerai dan Rujuk (NTCR). Sejak saat itu di setiap desa/kelurahan di Indonesia dibentuk Pembantu Pegawai Pencatat Nikah, Talak dan Rujuk (P3NTR). P3NTR ini sebenarnya sudah ada sebelumnya, namun dengan istilah yang bermacam-macam seperti Modin dan Kaum di Pulau Jawa, Amil di Sumatera dan Lebay di Kalimantan dan sebagian Sumatera. Saat itu keberadaan P3NTR ini tidak berdasar peraturan, kemunculan mereka bersifat spontan untuk membantu pencatatan nikah.

Aturan tentang P3NTR pertama kali diatur dalam Dalam Peraturan Menteri Agama Nomor 6 Tahun 1983 tentang Penunjukan dan Pemberhentian Serta Kewajiban dan Hak Pembantu Pegawai Pencatat Nikah. Sejak saat itu istilah P3NTR berubah menjadi Pembantu Pegawai Pencatat Nikah

${ }^{21}$ M. Anshary MK, Op Cit, h. 21.

Pogram Pascasarjana UIN Raden Intan Lampung 
(Pembantu PPN).

Kemudian PMA Nomor 6 Tahun 1983 diganti PMA Nomor 2 Tahun 1989 tentang Pembantu PPN. Dengan berlakunya PMA Nomor 2 Tahun 1989 dan surat edaran Dirjen Bimas Islam dan Urusan Haji No. D/ED/KP.00.2/02/1990 tentang pelaksanaan PMA No. 2 Tahun 1989 maka istilah "kaum/amil/modin/lebai" tidak ada lagi. Dalam PMA No. 2 Tahun 1989 tersebut diatur tugas pokok Pembantu PPN yaitu: Membantu pelayanan nikah dan rujuk dan melakukan pembinaan kehidupan beragama Islam di desa.

Kemudian keberadaan Pembantu PPN diatur kembali dalam Keputusan Menteri Agama Nomor 298 Tahun 2003 tentang Pencatatan Nikah. Berdasarkan KMA Nomor 298 Tahun 2003, Pengangkatan Pembantu PPN adalah dalam rangka untuk mendukung kinerja KUA dan melaksanakan pembinaan kehidupan beragama umat Islam terutama di desa. Di setiap desa/kelurahan seluruh Indonesia dapat diadakan Pembantu PPN. Pembantu PPN dalam melaksanakan kewajibannya berpedoman kepada peraturan perundangundangan yang berlaku dan bertanggung jawab kepada Kepala KUA.

Dalam PMA Nomor 11 Tahun 2007 tentang Pencatatan Nikah disebutkan bahwa Pembantu Pegawai Pencatat Nikah (Pembantu PPN) adalah anggota masyarakat tertentu yang diangkat oleh Kepala Kantor Departemen Agama Kabupaten/Kota untuk membantu tugas-tugas PPN di desa tertentu. ${ }^{22}$ Selanjutnya dalam PMA tersebut diatur mekanisme pengangkatan, pemberhentian, dan penetapan wilayah tugas Pembantu PPN dilakukan dengan surat keputusan Kepala Kantor Departemen Agama kabupaten/kota atas usul Kepala KUA dengan mempertimbangkan rekomendasi Kepala Seksi yang membidangi urusan agama Islam.

Mekanisme dan teknis pengangkatan Pembantu PPN

22PMA Nomor 11 Tahun 2007 tentang Pencatatan Nikah. 
berdasarkan pada Surat Edaran Direktur Jenderal Bimas Islam dan Penyelenggaraan Haji Nomor Dt.1.1/1/BA.00/1268/2005 tentang Pembantu Penghulu. Syarat-syarat calon Pembantu PPN sebagai berikut :

1) Warga Negara Republik Indonesia;

2) Beragama Islam;

3) Memahami Syariat Islam;

4) Setia pada Pancasila, UUD 1945, Negara dan Pemerintah RI serta tidak pernah terlibat dalam gerakan yang menentangnya;

5) Berakhlak mulia/berkelakuan baik;

6) Tidak pernah dihukum penjara atau kurungan berdasarkan keputusan pengadilan yang telah mempunyai kekuatan hukum tetap;

7) Berusia antara 25 sampai 56 tahun;

8) Lulus pendidikan sekurang-kurangnya Madrasah Aliyah atau sederajat;

9) Lulus testing yang diadakan khusus untuk itu yang diadakan oleh Kantor Kementerian Agama kabupaten/kota.

Materi testing calon Pembantu PPN adalah sebagai berikut: Pancasila dan UUD 1945, Undang-undang Nomor 1 Tahun 1974 tentang Perkawinan dan Peraturan Pelaksanaannya, Fikih Munakahat, Kompilasi Hukum Islam dan Fikih Ibadah, Tulis Baca Huruf al-Qur'an, Praktek khutbah nikah, doa upacara akad nikah dan memberikan penasehatan perkawinan.

Masa jabatan Pembantu PPN:

1) Masa jabatan Pembantu PPN adalah 5 tahun

2) Setelah habis masa tersebut yang bersangkutan dapat diangkat kembali

3) Usia pembantu Pembantu PPN setinggi-tingginya sampai usia 60 tahun

4) Dalam masa jabatan tersebut yang bersangkutan dapat diganti apabila dianggap; sudah tidak dapat melaksanakan kewajibannya sebagai Pembantu PPN. 
Tugas Pokok Pembantu PPN adalah: membantu pelayanan nikah dan rujuk dan melakukan pembinaan kehidupan beragama Islam di desa/kelurahan. Secara rinci tugas tersebut dapat diuraikan sebagai berikut :

1. Pelayanan Pencatatan Nikah dan Rujuk

a. Pembantu PPN di Jawa dapat membantu mengantar anggota masyarakat di wilayahnya yang berkepentingan dengan KUA Kecamatan yang mewilayahi dalam hal pemeriksaan nikah dan atau rujuk tersebut dalam buku menurut model N-10 dan R-2.

b. Pembantu PPN di luar Jawa atas nama PPN dapat mengawasi nikah dan menerima pemberitahuan rujuk.

c. Pembantu PPN dapat membantu PPN untuk menerima pemberitahuan kehendak nikah, memeriksa calon suami, calon isteri dan wali nikah tentang halangan pernikahan menurut model NB.

d. Pembantu PPN di luar Jawa membuat daftar pemeriksaan nikah rangkap 2.

e. Pembantu PPN membuat salinan dari daftar kedua, apabila lembar pertama daftar pemeriksaan nikah hilang dengan berita acara tentang sebab-sebab hilangnya lembar pertama tersebut.

f. Pembantu PPN membantu tugas PPN untuk memeriksa calon suami atau wali nikah yang ada diwilayahnya, dan mengirimkan hasil pemeriksaan tersebut kepada PPN.

g. Pembantu PPN membantu tugas PPN segera memberitahukan kepada calon suami dan wali nikah atau wakilnya, apabila ternyata dari hasil pemeriksaan terdapat halangan pernikahan menurut hukum Islam atau peraturn perundang-undangan tentang perkawinan dan atau belum dipenuhinya persyaratan / ketentuan dalam pelaksanaan pernikahan. 
h. Pembantu PPN membantu tugas PPN harus menolak pelaksanaan pernikahan yang ternyata tidak memenuhi syarat-syarat yang telah ditentukan.

i. Pembantu PPN membantu tugas PPN mengumumkan kehendak nikah yang telah memenuhi persyaratan pernikahan, dengan menempelkan pengumuman menurut model-NC di tempat yang mudah diketahui oleh umum.

j. Pembantu PPN membantu tugas PPN untuk memeriksa, meneliti dan menilai syarat-syarat rujuk.

k. Pembantu PPN membantu tugas PPN untuk menasehati suami istri tentang hukum-hukum dan kewajiban suami istri yang berkaitan dengan rujuk.

1. Pembantu PPN mengisi dan menandatangani daftar pemeriksaan rujuk, apabila pemeriksaan dilakukan di luar KUA Kecamatan dan dihadapan Pembantu PPN (model RB dibuat rangkap 2).

m. Pembantu PPN membuat salinan daftar model RB lembar kedua,apabila lembar pertama model RB hilang atau rusak, dengan berita acara yang menerangkan sebab-sebab lembar pertama tersebut hilang atau rusak.

n. Pembantu PPN menggunakan daftar pemeriksaan nikah dan daftar pemeriksaan rujuk.

o. Pembantu PPN membantu tugas PPN untuk mencatat daftar pemeriksaan nikah,akta nikah, buku nikah, buku pendaftaran cerai talak, buku pendaftaran cerai gugat, daftar pemeriksaan rujuk, buku pencatatan rujuk dn kutipan buku pencatatan rujuk serta formulir-formulir lainnya yang telah dibakukan.

p. Pembantu PPN membantu tugas PPN untuk membacakan hal-hal yang dicatat dihadapan yang berkepentingan dalam pelayanan nikah / rujuk, agar dapat dimengerti kebenaran pencatatan tersebut sebelum penandatanganan formulir. 
260 ljtimaiyya: Jurnal Pengembangan Masyarakat Islam 10 (2) (2017)

2. Pembinaan kehidupan beragama Islam di Desa/Kelurahan

Dalam PMA Nomor 2 Tahun 1989 tentang Pembantu PPN disebutkan bahwa Pembantu PPN selain memberikan pelayanan nikah dan rujuk juga mempunyai tugas melakukan pembinaan kehidupan beragam Islam di Desa. Pembinaan kehidupan beragama Islam di Desa dapat berupa kegiatan yang bersifat ubudiyah mahdhah (langsung berhubungan dengan Allah) dan dapat berupa kegiatan yang bersifat ubudiyah ijtimaiyah (hubungan antar sesama umat). Kegiatan pembinaan kehidupan beragama Islam tersebut meliputi antara lain:

a. Membina kerukunan masjid dari aspek idarah, imarah dan ri'ayah.

b. Mengkoordinasikan kegiatan peningkatan kemampuan baca tulis al-Qur'an (pengajian) di tiaptiap masjid serta mengusahakan buku-buku perpustakaan masjid.

c. Memberikan penasehatan kepada keluarga bermasalah.

d. Membina pengamalan ibadah sosial.

e. Mengkordinasikan dan menggerakkan lembagalembaga semi resmi yang membantu tugas Kementerian Agama (BKM, BP4, P2A dan LPTQ) di tingkat desa/kelurahan. ${ }^{23}$

\section{Hasil Penelitian}

a. Pembantu PPN di Kecamatan Natar

Masa kerja Pembantu PPN di Kecamatan Natar telah selesai sejak tahun 2013. Meskipun secara hukum tidak ada Pembantu PPN di Kecamatan Natar, namun dalam

${ }^{23}$ Direktorat Jenderal Bimbingan Masyarakat Islam dan Penyelenggaraan Haji Departemen Agama R.I, Pedoman Pembantu Pegawai Pencatat Nikah, (Jakarta, 2004), h. 4. 
prakteknya Pembantu PPN masih melaksanakan tugas menghadiri pelaksanaan akad nikah yang seharusnya dilakukan PPN atau Penghulu.

KUA Kecamatan Natar merupakan KUA dengan tipologi A, yaitu KUA yang rata-rata jumlah peristiwa nikah atau rujuknya di atas 100 peristiwa perbulan. Dengan jumlah peristiwa nikah yang tinggi dan wilayah yang luas, KUA Kecamatan Natar membutuhkan petugas pencatat nikah yang banyak pula. Saat ini di KUA Kecamatan Natar terdapat satu orang PPN dan empat orang penghulu.

Menurut Kepala KUA Kecamatan Natar Wawang Sanwari, dengan jumlah petugas lima orang tersebut, pihaknya masih dapat melayani proses pengawasan nikah. Kecuali dalam kondisi tertentu saat peristiwa nikah banyak maka Pembantu PPN diperbantukan kembali. ${ }^{24}$

Keberadaan Pembantu PPN sangat penting tidak hanya bagi masyarakat, namun juga bagi Kementerian Agama. Banyak tugas-tugas Kementerian Agama yang tidak dapat dilakukan oleh Kepala KUA atau Penghulu. Keberadaan Pembantu PPN di tengah-tengah masyarakat menjadikan mereka lebih tahu kondisi masyarakat di kelurahan. Masyarakat juga masih melihat peran mereka masih sangat dibutuhkan dalam kehidupan sosial keagamaan. ${ }^{25}$

b. Pembantu PPN di Kecamatan Padang Cermin

KUA Padang Cermin memiliki satu orang PPN dan dua orang Penghulu. Dari 31 desa di kecamatan Padang Cermin terdapat seorang Pembantu PPN.

Sejak ditetapkannya instruksi Dirjen Bimas Islam nomor DJ.II/1 tahun 2015 Kementerian Agama Kabupaten Pesawaran tidak dapat mengangkat Pembantu PPN di kecamatan Padang Cermin. Namun mengingat kondisi wilayah dan jumlah peristiwa nikah tidak sebanding dengan Mei 2017

${ }^{24}$ Wawang Sanwari, Kepala KUA Kec. Natar, Wawancara, Tanggal 3

${ }^{25}$ Nano Sholahuddin, Pembantu PPN, Wawancara, Tanggal 3 Mei 2017 
jumlah PPN dan Penghulu, maka Pembantu PPN di KUA Padang Cermin masih diperbantukan untuk melaksanakan pencatatan nikah yaitu menghadiri pelaksanaan akad nikah. ${ }^{26}$ Menurut Pembantu PPN Desa Sukajaya Lempasing Bapak Asy'ari peraturan tersebut belum dapat diterapkan untuk saat ini. Masyarakat di Pesawaran terutama suku Lampung menempatkan Pembantu PPN sebagai tokoh agama sekaligus adat. $^{27}$

c. Pembantu PPN di Kecamatan Tanjung Karang Pusat KUA Tanjung Karang Pusat merupakan KUA dengan tipologi C. KUA Tanjung Karang Pusat menaungi dua kecamatan yaitu kecamatan Tanjung Karang Pusat dan Kecamatan Enggal. Kecamatan Enggal masuk ke dalam kewenangan KUA Tanjung Karang Pusat karena belum memiliki KUA definitif tersendiri. KUA Tanjung Karang Pusat memiliki satu orang PPN dan satu orang Penghulu.

Sejak adannya intstruksi penghentian pengangkatan Pembantu PPN, pihaknya tidak lagi menugaskan Pembantu PPN untuk melaksanakan pemeriksaan dan pengawasan akad nikah bagi Pembantu PPN yang SK-nya telah berakhir. Namun hal tersebut bukan tidak ada kendala sama sekali. Misalnya kebiasaan masyarakat melaksanakan akad nikah pada hari Sabtu dan Minggu menyebabkan penumpukan jadwal nikah. Sementara jumlah PPN dan Penghulu tidak cukup untuk menangani pelaksanaan akad nikah pada 13 kelurahan pada hari yang sama. Oleh karena itu dalam keadaan darurat seperti itu KUA mengambil inisiatif menugaskan Pembantu PPN untuk menghadiri akad nikah.” 28

\footnotetext{
${ }^{26}$ Hayatul Kirom, Pembantu PPN, Wawancara, Tanggal 23 September 2016

${ }^{27}$ Asy'ari, Pembantu PPN, Wawancara, Tanggal 25 September 2016

${ }^{28}$ H. M. Syaifullah, Pembantu PPN, Wawancara, Tanggal 20 September 
d. Pembantu PPN di Kecamatan Marga Punduh

KUA Kecamatan Marga Punduh merupakan KUA dengan tipologi D1. Penetapan KUA Marga Punduh sebagai KUA dengan tipologi D1 adalah berdasarkan kondisi wilayah kecamatan Marga Punduh yang terletak di pegunungan dan kepulauan. Di Kecamatan Marga Punduh terdapat satu desa yang terletak di sebuah pulau, yaitu Desa Pulau Pahawang.

Menurut para Pembantu PPN di wilayah KUA Marga Punduh, sejak berlakunya instruksi Dirjen Bimas Islam nomor DJ.II/1 tahun 2015 tentang Pengangkatan Pembantu PPN tidak ada perpanjangan SK pengangkatan. Namun karena masih dibutuhkan oleh KUA Kecamatan, mereka mengaku masih menjalankan tugas-tugas Pembantu PPN. ${ }^{29}$

Terkait Instruksi Dirjen Bimas Islam tentang pengangkatan Pembantu PPN, Kantor Kementerian Agama Kabupaten Pesawaran mematuhi instruksi tersebut. Namun pihak Kementerian Agama Kabupaten Pesawaran masih melihat perkembangan apakah perlu memperpanjang masa kerja Pembantu PPN. Meskipun semua Pembantu PPN telah habis masa tugasnya namun sebagian tetap menjalankan tugas memimpin prosesi akad nikah. ${ }^{30}$

\section{d. Catatan Akhir Dalam Penataan Pembantu PPN}

Keberadaan Pembantu PPN yang telah ada sejak lama menjadikan keberadaan mereka mengakar kuat dalam masyarakat. Bahkan banyak masyarakat beranggapan bahwa Pembantu PPN adalah penghulu satu-satunya yang berwenang melakukan pencatatan nikah. Sehingga masyarakat yang akan menikah bukan datang ke KUA, melainkan ke Pembantu PPN. Hal ini karena Pembantu PPN berada langsung di tengah-tengah masyarakat dan berhadapan langsung dengan masyarakat. Selain itu ketokohan Pembantu

\footnotetext{
${ }^{29}$ Masrudin, Pembantu PPN, Wawancara, Tanggal 21 Maret 2017

${ }^{30}$ Helmi, W awancara, Tanggal 9 Agustus 2016
} 
PPN sebagai ulama juga berperan penting dalam eksistensi mereka.

Terbitnya Instruksi Dirjen Bimas Islam Nomor Dj.II/1 Tahun 2015 yang mengatur pembatasan pengangkatan Pembantu PPN pada wilayah tertentu merupakan upaya pemerintah menertibkan pencatatan nikah di KUA. Dengan adanya Instruksi ini diharapkan terwujud kemaslahatan bagi semua pihak yang terkait yaitu pemerintah (Kementerian Agama), Pembantu PPN dan masyarakat. Tidak dapat dipungkiri bahwa Pembantu PPN merupakan pihak yang paling dirugikan akibat adanya Instruksi ini. Mereka yang tadinya punya kewenangan dan status di masyarakat, harus kehilangan semua itu. Namun jika ditelaah lebih jauh muara dari semua ini terwujudnya kemaslahatan dalam pencatatan nikah. Kondisi wilayah KUA kecamatan dan minimnya petugas KUA yang tersebar di seluruh Indonesia menjadikan banyak pencatatan nikah dan tugastugas KUA lainnya tidak dapat dilaksanakan dengan maksimal. Oleh karena itu, dalam Peraturan Menteri Agama Nomor 6 Tahun 1983 tentang Pembantu PPN dimungkinkan untuk mengangkat Pembantu PPN. Peraturan Menteri Agama Nomor 11 Tahun 2007, Pasal 1 ayat 4 menegaskan, bahwa Pembantu PPN adalah anggota masyarakat tertentu yang diangkat oleh Kepala Kantor Departemen Agama kabupaten/kota untuk membantu tugas-tugas PPN di desa tertentu. ${ }^{31}$

Diangkatnya Pembantu PPN adalah untuk mempermudah dan memperdekat jarak pelayanan kepada masyarakat yang ingin melaksanakan proses akad nikah. Apalagi yang derahnya luas dan akses transportasinya sulit dijangkau, seperti daerah pegunungan dan kepulauan. Selain itu tugas Pembantu PPN adalah melaksanakan pembinaan dan bimbingan agama Islam bagi masyarakat muslim.

Namun sebagai kepanjangan tangan Kepala KUA di

${ }^{31}$ Pasal 1 ayat 4 PMA Nomor 11 Tahun 2007 
wilayah kelurahan/desa, banyak ditemukan kelemahan dalam pengangkatan Pembantu PPN. Secara legal formal, saat studi dilakukan, masa bakti Pembantu PPN telah habis. Namun demikian, sebagian Pembantu PPN masih melaksanakan tugas, karena masyarakat masih membutuhkan pelayanan dari yang bersangkutan. Hal inilah yang menurut peneliti menjadi beban dalam pelaksanaan pencatatan nikah. Selain itu, belum ada standar kerja bagi Pembantu PPN dalam pelayanan kepada masyarakat.

Sesuai dengan instruksi yang telah diterbitkan oleh Dirjen Bimas Islam tersebut, Kementerian Agama Kabupaten dan Kota di Provinsi Lampung telah melaksanakan intruksi tersebut. Yakni tidak memperpanjang masa kerja Pembantu PPN dan mengangkat Pembantu PPN baru. Kementerian Agama juga berkomitmen melepaskan tugas Pembantu PPN dalam pelaksanaan pencatatan nikah.

Dalam hal implementasi instruksi tersebut, Pembantu PPN memang sangat dirugikan. Sebab ketika ketika mereka dihapuskan, juga berakibat dengan hilangnya pekerjaan mereka yang telah diemban sebelumnya. Oleh karena itu Kementerian Agama hendaknya berkordinasi dengan pemerintah daerah terkait nasib Pembantu PPN. Kementerian Agama dapat mengusulkan alih fungsi petugas Pembantu PPN dengan memaksukkan mereka ke dalam struktur pemerintahan desa.

Peraturan yang dibuat hendaknya dilihat sebagai suatu gejala yang dapat diamati di dalam aparat Kementerian Agama dan budaya masyarakat. Hal ini menunjukkan bahwa ada hal lain yang harus diperhatikan di luar hukum. Problem dalam penataan Pembantu PPN dapat dilihat dari tiga aspek; Pertama, aspek kelembagaan. Kedua, Aspek Peraturan. Ketiga Aspek hukum. Jika dicermati hal ini sesuai dengan apa yang dikemukakan oleh Lawrence M. Friedman bahwa dalam suatu sistem hukum dibutuhkan beberapa komponen. Friedman 
membagi ke dalam tiga komponen yaitu struktur, substansi, dan kultural. ${ }^{32}$

Pertama Struktur adalah kelembagaan yang yang diciptakan oleh sistem hukum dengan tujuan untuk mendukung bekerjanya sistem hukum itu sendiri. ${ }^{33}$ KUA dibentuk berdasarkan kebutuhan masyarakat dalam hal pencatatan nikah. Jadi tujuan pembentukan KUA yaitu merupakan perwakilan dari pemerintah yang berkewajiban untuk melayani warga Negara dalam pengurusan pernikahan. Dalam melaksakan tugas pencatatan nikah ini di dalam KUA terdapat personil yaitu Pegawai Pencatat Nikah (PPN).

Dalam melaksanakan tugas pencatatan perkawinan, PPN dapat diwakili oleh Penghulu atau Pembantu Pegawai Pencatat Nikah (Pembantu PPN). ${ }^{34}$ Keberadaan Pembantu PPN dalam peraturan tersebut adalah mewakili PPN dalam tugas pencatatan nikah. Seharusnya yang namanya wakil adalah melaksanakan tugas ketika yang diwakilinya tidak dapat melaksanakan tugas. Namun masyarakat banyak tidak tahu tentang kewenangan pencatatan nikah di KUA.

Lemahnya mentalitas aparatur pada Kementerian Agama dan petugas pencatat nikah mengakibatkan penegakkan aturan penataan pembantu PPN tidak berjalan sebagaimana mestinya. Banyak faktor yang mempengaruhi lemahnya mentalitas aparatur Kementerian Agama di antaranya lemahnya pemahaman peraturan, ekonomi, proses rekruitmen yang tidak transparan dan lain sebagainya. Sehingga dapat dipertegas bahwa faktor petugas aparatur pada Kementerian Agama dan petugas pencatat nikah memainkan peran penting dalam memfungsikan aturan Pembantu PPN. Kalau peraturan sudah baik, tetapi kualitas penegak hukum rendah maka akan ada masalah. Demikian

\footnotetext{
${ }^{32}$ Lawrence Meier Friedman, The Legal System: A Social Science Perspective, (New York: Russel Sage Foundation, 1975), h. 15.

${ }^{33}$ Muslah Abdurrahman, Sosiologi dan Metode Penelitian Hukum. (Malang: UMM Press, 2009), h. 46.

${ }^{34}$ Pasal 3 ayat 1 PMA Nomor 11 Tahun 2007
} 
juga, apabila peraturannya buruk sedangkan kualitas penegak SDM , kemungkinan munculnya masalah masih terbuka.

Kedua yaitu komponen substansi yang berupa normanorma hukum, baik berupa peraturan, keputusan dan sebagainya yang semuanya digunakan untuk melaksanakan hukum (peraturan). Menurut Friedman substansi merupakan komponen-komponen riil dari sebuah sistem hukum. ${ }^{35}$ Jika komponen ini dihubungkan dengan instruksi yang menjadi operasional kerja penataan Pembantu PPN. Maka, hal yang perlu dicermati apakah Instruksi tersebut telah memadai sebagai sebuah landasan usaha penataan Pembantu PPN.

Berdasarkan penelitian, instruksi pertama yaitu Instruksi Nomor DJ.II/113 Tahun 2009 tentang Penggunaan Dana PNBP Nikah dan Rujuk dan Penataan Pembantu PPN memiliki kekurangan terutama pada ketentuan poin kedua terdapat intruksi kepada Kepala Kantor Wilayah Kementerian Agama Provinsi di seluruh Indonesia sebagai berikut :

Melakukan penghentian pengangkatan terhadap Pembantu Pegawai Pencatat Nikah yang telah habis masa waktunya dan tidak mengangkat Pembantu Pegawai Pencatat Nikah baru, kecuali daerah-daerah yang sangat memerlukan dengan persetujuan tertulis dari Dirjen Bimas Islam. Ketentuan tersebut tidak disertakan dengan penjelasan daerah mana yang termasuk sangat memerlukan Pembantu PPN. Akibatnya hampir seluruh daerah tetap mengangkat Pembantu PPN dengan alasan sangat memerlukan. Jika memang pemerintah ingin menghapuskan Pembantu PPN maka diperlukan sarana dan prasarana agar masyarakat langsung mendaftar nikah di KUA. Selain itu pemerintah juga harus menyiapkan petugas penghulu PNS yang cukup untuk melayani pencatatan nikah. Sarana dan prasarana sangat dibutuhkan dalam mencapai ketertiban sebagaimana dikatakan oleh Soerjono Soekanto bahwa salah satu

${ }^{35}$ Lawrence Meier Friedman, The Legal System, h. 16 
pendukung agar hukum atau peraturan bisa berjalan efektif maka dibutuhkan sarana dan prasarana pendukung.

Ketiga yakni kultur, yang dimaksud dengan kultur yaitu budaya yang sudah dilakukan oleh masyarakat dan memiliki nilai yang kuat dalam kehidupan masyarakat. Kultur hukum menurut Lawrence Meir Friedman adalah sikap manusia terhadap hukum dan sistem hukum-kepercayaan,nilai, pemikiran, serta harapannya. Kultur hukum adalah suasana pemikiran sosial dan kekuatan sosial yang menentukan bagaimana hukum digunakan, dihindari, atau disalahgunakan. Budaya hukum erat kaitannya dengan kesadaran hukum masyarakat. Semakin tinggi kesadaran hukum masyarakat maka akan tercipta budaya hukum yang baik dan dapat merubah pola pikir masyarakat mengenai hukum selama ini. Secara sederhana, tingkat kepatuhan masyarakat terhadap hukum merupakan salah satu indikator berfungsinya hukum.

Hubungan antara tiga unsur sistem hukum itu sendiri tak berdaya, seperti pekerjaan mekanik. Struktur diibaratkan seperti mesin, substansi adalah apa yang dikerjakan dan dihasilkan oleh mesin, sedangkan kultur hukum adalah apa saja atau siapa saja yang memutuskan untuk menghidupkan dan mematikan mesin itu, serta memutuskan bagaimana mesin itu digunakan. Dikaitkan dengan penataan Pembantu PPN melalui Instruksi Dirjen Bimas Islam Nomor Dj.II/1 Tahun 2015 tentang Pengangkatan Pembantu PPN, teori Friedman tersebut dapat kita jadikan patokan dalam mengukur proses penataan Pembantu PPN. Pembantu PPN adalah bagian dari struktur bersama dengan organ PPN dan Penghulu, Interaksi antar komponen petugas pencatat nikah ini menentukan kokoh nya struktur hukum. Walau demikian, tegaknya Instruksi Dirjen Bimas Islam Nomor Dj.II/1 Tahun 2015 tidak hanya ditentukan oleh kokohnya struktur, tetapi juga terkait dengan kultur hukum di dalam masyarakat. Namun demikian, hingga kini ketiga unsur sebagaimana dikatakan oleh Friedman belum dapat terlaksana dengan baik, khususnya dalam struktur hukum dan budaya hukum. Sebagai 
contoh, dalam struktur hukum, PPN yang diharapkan melaksanakan pencatatan nikah, namun yang melaksanakan justru Pembantu PPN yang telah habis SK pengangkatannya.

Untuk mengubah budaya hukum yang ada pada masyarakat kita harus selalu memahami tentang nilai-nilai, tradisi, kebiasaan, dan segala sikap dominan yang berlaku pada semua aspek hidup masyarakat. memberikan pemahaman tentang arti hukum dan peraturan itu sendiri, bahwa pencatatan nikah adalah kewenangan PPN yang ada di KUA Kecamatan. Sudah seharusnya warga yang akan menikah hendaknya mengurus pencatatan nikahnya langsung kepada petugas resmi yang ada di KUA kecamatan.

Berdasarkan penelitian yang telah dilakukan terhadap 4 tipologi KUA Kecamatan yang ada di Provinsi Lampung yaitu : KUA Kecamatan Natar (Tipologi A), KUA Kecamatan Padang Cermin (Tipologi B), KUA Kecamatan Tanjung Karang Pusat (Tipologi C) dan KUA Kecamatan Marga Punduh (Tipologi D1), penulis berpendapat bahwa pencatatan nikah sebaiknya dilakukan oleh PPN atau Penghulu. Ketergantungan KUA kepada Pembantu PPN disebabkan kekurangan jumlah Penghulu.

Pembantu PPN yang telah selesai masa kerjanya namun masih menghadiri pelaksanaan akad nikah rentan menyebabkan terjadinya pembengkakan biaya pencatatan nikah. Pembantu PPN tersebut tidak mendapat honor dan penggantian biaya transportasi dari Penerimaan Negara Bukan Pajak atas biaya nikah dan rujuk. Namun Pembantu PPN mendapat imbalan dari pengantin. Sehingga masyarakat harus membayar lebih dalam menerima pelayanan pencatatan nikah.

\section{Kesimpulan}

Berdasarkan penelitian yang dilakukan mengenai keberadaan dan pelaksanaan tugas Pembantu PPN pasca Instruksi Dirjen Bimas Islam Nomor DJ.II/1 Tahun 2015 tentang Pengangkatan Pembantu Pegawai Pencatat Nikah Di 
KUA Kecamatan Natar, Padang Cermin, Tanjung Karang Pusat dan Marga Punduh, dapat disimpulkan hal-hal sebagai berikut :

1. Sejak ditetapkannya Instruksi Dirjen Bimas Islam Nomor DJ.II/1 Tahun 2015 tentang Pengangkatan Pembantu Pegawai Pencatat, tidak ada lagi perpanjangan masa kerja dan tidak ada pengangkatan Pembantu PPN baru.

2. Sejak ditetapkannya Instruksi Dirjen Bimas Islam Nomor DJ.II/1 Tahun 2015 tentang Pengangkatan Pembantu Pegawai Pencatat Nikah, Pembantu PPN di KUA Tanjung Karang Pusat Kota Bandar Lampung tidak lagi melaksanakan tugas-tugas sebagai Pembantu PPN. Sedangkan di KUA Kecamatan Natar, KUA Kecamatan Padang Cermin dan KUA Kecamatan Marga Punduh sebagian Pembantu PPN masih melaksanakan tugas pencatatan nikah. 


\section{Daftar Pustaka}

Abdurrahman, Muslah, Sosiologi dan Metode Penelitian Hukum. Malang: UMM Press, 2009

As'ad, Abd. Rasyid, Urgensi Pencatatan Perkawinan Dalam Perspektif Filsafat Hukum, http://www.arsip.badilag.net/ diakses tanggal 24 Juni 2016.

Direktorat Jenderal Bimbingan Masyarakat Islam dan Penyelenggaraan Haji Departemen Agama R.I, Pedoman Pembantu Pegawai Pencatat Nikah, Jakarta, 2004

Direktorat Jenderal Bimbingan Masyarakat Islam Kementerian Agama RI, Himpunan Peraturan Perundangundangan Perkawinan, Jakarta : 2015

Friedman, Lawrence Meier, The Legal System: A Social Science Perspective, New York: Russel Sage Foundation, 1975

Hadikusuma, Hilman, Hukum Perkawinan Indonesia Menurut Perundangan, Hukum Adat, Hukum Agama, Bandung: CV. Mandur Maju, 2007

http://www.republika.co.id/berita/dunia-islam/islamnusantara/16/03/04/o3i6w7313-menag-surat-tugasp3n-tidak-diperpanjang, diakses tanggal 26 September 2016

Kamus Besar Bahasa Indonesia Online, http://kbbi.web.id/catat diakses tanggal 14 September 2016.

MK, M. Anshary, Hukum Perkawinan di Indonesia, Yogyakarta: Pustaka Pelajar, 2010

Mudzhar, M. Atho', Membaca Gelombang Ijtihad, Antara Tradisi dan Liberasi, Yogyakarta: Titian Ilahi Press, 1998

O.S. Eoh, Perkawinan Antar Agama Dalam Teori dan Praktek, Jakarta: PT Raja Grafindo Persada, 1996

Pencatatan Perkawinan Dalam Hukum Islam, https://aljurem.wordpress.com/ diakses tanggal 23 Februari 2017. 
Peraturan Menteri Agama Nomor 12 Tahun 2016 tentang Pengelolaan PNBP Atas Biaya Nikah atau Rujuk di Luar KUA Kecamatan.

Peraturan Pemerintah Republik Indonesia Nomor 9 Tahun 1975 Tentang Pelaksanaan Undang-Undang Nomor 1 Tahun 1974 Tentang Perkawinan

Pernyataan Menteri Agama Lukman Hakim Saifudin saat konferensi pers kegiatan Rakor Kemenag di Palembang, https://nrmnews.com/2016/03/04/kementerianagama-tak-perpanjang-surat-tugas-p3n/ diakses 28 September 2016.

PMA Nomor 11 Tahun 2007tentang Pencatatan Nikah.

Pungli Biaya Pernikahan Marak di Jateng Lewat Jasa Modin, https://m.tempo.co/, diakses tanggal 14 September 2016

Rofiq, Ahmad, Hukum Perdata Islam di Indonesia Jakarta: PT RajaGrafindo Persada,2013

Saleh, K. Wantjik, Hukum Perkawinan Indonesia, Jakarta: Ghalia Indonesia, 1982

Soemiyati, Hukum Perkawinan Islam dan Undang-Undang Perkawinan, Yogyakarta: Liberty, 1999

Subekti, Hukum Keluargadan HukumWaris, Jakarta: PT.Intermasa, 2002

Surat Keputusan Kepala Kantor Wilayah Kementerian Agama Provinsi Lampung Nomor Kw.08.5/HK.00.8/097/2015 tentang Penetapan Tipologi Kantor Urusan Agama Kecamatan Di Lingkungan Kanwil Kementerian Agama Provinsi Lampung.

Syarifuddin, Amir. Hukum Perkawinan Islam di Indonesia. Jakarta: Prenada Media, 2006 